\title{
AGROTEKNIKA
}

\section{Alat Pembuat Pupuk Cair Otomatis dari Limbah Tandan Kosong Kelapa Sawit Berbasis Mikrokontroller}

\section{Microcontroller-Based Liquid Fertilizer Developer from Palm Empty Fruit Bond Waste}

\author{
Ridho Nurrohmanysah*, Anggia Indriyani, Ekaliana, Mareli Telaumbanua \\ Fakultas Teknologi Pertanian, Universitas Lampung
}

*Penulis Korespondensi

Email: ridhonur39@gmail.com

\begin{abstract}
Abstrak. Potensi produksi kelapa sawit yang besar di provinsi Lampung memiliki dampak terhadap peningkatan produksi bahan sisa yang tidak terolah salah satunya adalah tandan kosong kelapa sawit (TKKS). TKKS dikategorikan sebagai limbah padat organik yang mempuyai potensi untuk dimanfaatkan sebagai pupuk organik. Namun dalam proses pembuatan pupuk organik ini mempunyai beberapa kendala salah satunya waktu penguraian (dekomposisi) tkks yang lambat yang berdampak pada kebutuhan lahan untuk proses tersebut semakin luas dan biaya yang dikeluarkan juga semakin besar. Salah satu upaya yang dapat dilakukan untuk mengatasi hal tersebut yaitu dengan menggunakan teknologi yang terintegrasi dan sistem terpadu guna mempermudah dalam pembuatan pupuk selama proses dekomposisi. Alat ini mengaduk bahan secara otomatis dan memiliki sensor suhu untuk memprediksi tinggi dan rendahnya suhu pada proses dekomposisi. Rancangan alat ini berhasil dirancang dan dilakukan pengujian menggunakan air di dalam wadah penampungan ( selama 5 hari) sehingga menghasilkan kinerja alat pengaduk sebesar 68\% dengan kecepatan respon alat dalam mengaduk ialah $\pm 1 \mathrm{mS}$. Persentase kinerja 99,8\% untuk pompa pengaduk dan respon penyalaan kran otomatis sebesar \pm $1 \mathrm{mS}$.
\end{abstract}

Kata kunci: sawit, dekomposisi, TKKS, kinerja alat

Abstract. The large potential of oil palm production in Lampung province has an impact on increasing the production of untreated residual materials, one of which is oil palm empty fruit bunches (OPEFB). OPEFB is categorized as organic solid waste which has the potential to be used as organic fertilizer. However, in the process of making organic fertilizer, there are several constraints, one of which is the slow decomposition of time and time which has an impact on the need for more extensive land and the costs incurred. One effort that can be done to overcome this is by using integrated technology and integrated systems to facilitate the manufacture of fertilizers during the decomposition process. This tool stirs the material automatically and has a temperature sensor to predict the high and low temperatures in the decomposition process. The design of this tool was successfully designed and tested using water in a storage container (for 5 days), resulting in a stirrer performance performance of $68 \%$ with a response speed of the stirring tool at $\pm 1 \mathrm{mS}$. The performance percentage of $99.8 \%$ for the stirring pump and automatic faucet ignition response is $\pm 1 \mathrm{mS}$.

Keywords palm, decomposition, OPEFB, the performance of the tool

\section{Pendahuluan}

Provinsi Lampung merupakan salah satu daerah penghasil kelapa sawit di wilayah Sumatera bagian Selatan. Ada 4 wilayah yang menjadi andalan utama dalam pengembangan 
kelapa sawit ini yaitu Lampung Tengah, Tulang Bawang, Way Kanan dan Mesuji. Tahun 2017, hasil kelapa sawit di Lampung mencapai 400 ton dengan luas lahan sebesar 256 ha (BUMN, 2018). Potensi produksi sawit yang besar berdampak terhadap peningkatan produksi bahan sisa yang tidak terolah salah satunya tandan kosong kelapa sawit (TKKS). Setiap hari pabrik melakukan pengolahan yang menghasilkan ratusan ton TKKS (Simatupang et al., 2012).

TKKS dikategorikan sebagai limbah padat organik yang memiliki sifat fisik dan kimia. Eka (2000) menyatakan bahwa TKKS memiliki kandungan lignin 22,60 \%, pentosan 25,90 \%, aselulosa $45,80 \%$, holoselulosa $71,88 \%$, abu 1,6\% dan pektin 12,85\%. Limbah ini mempuyai potensi untuk dimanfaatkan sebagai pupuk organik. Hal ini diperkuat dalam penelitian Warsito et al., (2016) bahwa analisis kadar rata- rata nitrogen ( $\mathrm{N}$ ) dan phosporus sebesar 2,033 \% dan 0,107 \%, kadar abu sebesar 36,6\% dan kadar air sebanyak 47,53\% Secara harfiah pupuk organik merupakan pupuk yang sebagian besar atau seluruh penyusunnya berasal dari tanaman atau hewan dan telah melalui proses rekayasa yang dapat berbentuk padat atau cair (Dwicaksono et al., 2013). Penggunaan pupuk organik akan memperbaiki sifat tanah yang berdampak pada pertumbuhan bagi tanaman. Pemberian pupuk ini akan meningkatkan porositas tanah sebesar 79,8\% dan meningkatkan jumlah daun, berat basah atau berat kering tanaman, dan pertambahan tinggi (Anastasia et al., 2014).

Proses pembuatan pupuk organik dari TKKS terkendala oleh beberapa hal, salah satunya penguraian TKKS yang lama. TKKS merupakan bahan organik yang sukar terdekomposisi karena strukturnya yang keras dan ukuran yang besar. Kandungan lignin yang tinggi juga menghambat proses dekomposisi ini (Saraswati et al., 2017). Senyawa lignin ini berfungsi untuk membuat kekakuan pada tanaman, menurunkan permeasi air yang melintasi dinding sel, dan membuat resisten terhadap mikroba. Lamanya proses dekomposisi akan berdampak pada kebutuhan lahan untuk proses tersebut semakin luas dan biaya yang dikeluarkan juga semakin besar. Oleh sebab itu, untuk mengatasi permasalahan yang ada, diperlukan sebuah teknologi yang tepat agar proses dekomposisi dapat berjalan dengan efektif dan efisien. Salah satu upaya yang dapat dilakukan yaitu dengan menggunakan alat pembuat pupuk cair otomatis dari limbah tandan kosong kelapa sawit berbasis mikrokontroler.

Penggunaan teknologi tepat guna telah banyak diterapkan dalam pembuatan pupuk. Salah satunya penelitian dari Nurisman (2019) yang merancang alat pengolah ampas tahu menjadi pupuk cair dengan pengepresan pneumatic. Alat tersebut mempunyai kinerja keseluruhan sebesar $70 \%$ dalam proses pengepresan dan pengukuran $\mathrm{pH}$ hasil pupuk. Penelitian lainnya dilakukan oleh Sucipto and Hendariyono (2018) yang merancang disck granulator pembuat pupuk organik granul secara lab. Alat tersebut menghasilkan efesiensi tingkat keseragaman granul 3-5 mm mencapai $86,70 \%$ dengan bahan baku $20 \mathrm{~kg}$ dan granulasi selama 15 menit. 
Penerapan teknologi tepat guna merupakan salah satu upaya penanganan permasalahan yang ada dilingkungan, terutama mengenai keterkaitan dengan limbah organik. Salah satu yang diterapkan ialah perancangan alat pembuatan pupuk yang sudah terintegrasi. Penelitian yang dilakukan oleh Joewono and Agustien (2015) yang merancang komposter otomatis-elektrik tenaga surya untuk pengolahan sampah organik. Alat ini digunakan dalam penanganan limbah organik di daerah pembuangan sampah sementara di kampung Mojoarum kelurahan mojo kecamatan Gubeng, Surabaya. Sementara teknologi otomasi juga banyak dimanfaatkan, salah satunya dalam pengendalian suhu dan kelembaban. Pengendalian faktor-faktor ini sangat penting untuk proses pembuatan pupuk organik yang baik dan dalam jangka waktu cepat (Supriatna, Putri, \& Nanik, 2015).

Penerapan teknologi yang terintegrasi dan sistem terpadu dalam proses dekomposisi mengubah limbah tkks menjadi pupuk organik menjadi salah satu trobosan terbaru. Dengan menggunakan teknologi otomasi dalam pengolahan TKKS menjadi sumber pupuk akan di dapatkan pupuk organik secara kontinyu dan efiseinsi yang besar. Oleh sebab itu dilakukan perancangan alat pembuat pupuk cair otomatis dari limbah TKKS guna menangani permasalahan yang dihadapi dan mendukung revolusi industri 4.0.

\section{Bahan dan Metode}

\subsection{Alat dan Bahan}

Alat- alat yang dibutuhkan dalam proses pembuatan sistem ini yaitu timbangan, multimeter, gergaji, solder, obeng, mikrokontroller arduino atmega serta laptop yang sudah terinstal software aplikasi eagle dan arduino ide untuk pembuatan rangkaian dan pemograman.

Bahan-bahan yang dibutuhkan dalam pembuatan sistem adalah komponen elektronika seperti sensor suhu LM35 DZ, liquid cristal display (LCD) yang dilengkapi dengan I2C dan 2 lembar PCB (Printed Circuit Board) single layar dengan ukuran $20 \mathrm{~cm}$ x $10 \mathrm{~cm}$. Selain itu membutuhkan resistor $10 \mathrm{kohm}$, kapasitor, pin deret, 25 black housing 10 pin. 40 spacer (Penyangga modul), kabel warna (jumper), 3 lembar kertas glossy, 25 LED (Light emitted diode), pompa Aquarium AC, 6 drum plastik (Chamber $50 \mathrm{~L}$ ), pompa udara kapasistas 4L/menit, Relay DC 5V dan $12 \mathrm{~V}$, transistor TPI120 serta 1 buah box untuk penyimpan modul.

\subsection{Perancangan Alat}

Alat yang dirancang memiliki 6 drum sebagai tempat penampungan bahan. Di dalam drum terdapat batang pengaduk yang membantu proses pengadukan dan pergerakannya dibantu oleh gearbox. Kran otomatis juga di letakan pada setiap drum nya. Pada sistem otomatis terdapat pompa udara yang mengalirkan udara kedalam drum untuk membantu proses fermentasi nantinya. Secara menyeluruh tiap bagian komponen alat saling terintegrasi dengan Mikrokontroller Arduino 
Atmega 2560. Arduino ini berfungsi sebagai otak pergerakan. Komponen ini akan melaksanakan tugas dalam pengolahan informasi suhu, pemberian waktu, menampilkan dara pada LCD, serta mengatur waktu meghidupkan atau mematikan pengadukan dan pompa udara atau kran otomatis.

Proses pabrikasi dilakukan di bengkel Daya Alat Mesin Pertanian, Jurusan Teknik Pertanian, Fakultas Pertanian, Universitas Lampung. Dalam proses pembuatan alat ini diperlukan alat-alat utama seperti bor tangan, las, gergaji besi dan solder. Bor tangan ini berfungsi sebagai tempat untuk membuat lubang tempat masuk baut dan mur. Mesin las berfungsi untuk mengelas bagian kerangka utama alat. Gergaji besi berfungsi untuk memotong bagian-bagian alat dan rangka utama. Solder berfungsi untuk menyambungkan rangkaian alat elektronika. Rancangan alat ditunjukkan oleh Gambar 1.

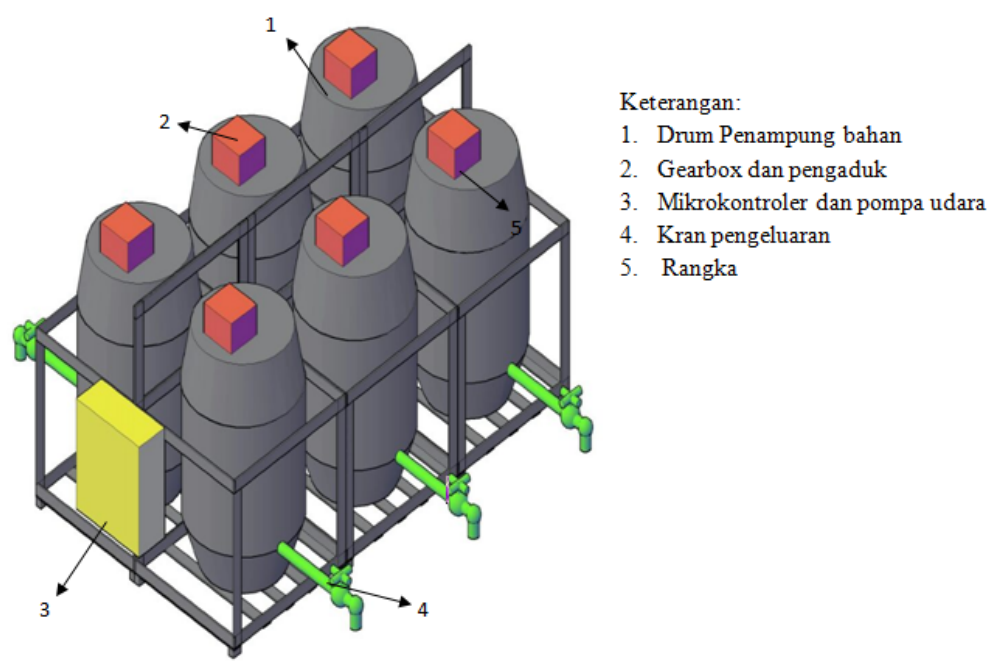

Gambar 1. Desain alat

\subsection{Mekanisme Kerja Alat}

Alat dirancang untuk bekerja secara otomatis baik dalam pengadukan dan pemberian udara ke dalam drum. Pada proses pengadukan dilakukan pengaturan waktu pengadukan pada drum setiap 6 jam sekali setiap hari. Pengaturan waktu pengadukan pada jam 6 pagi, jam 12 siang, jam 6 sore, dan jam 12 malam. Tujuan pengadukan agar material bahan tercampur merata sehingga proses penguraian ( dekomposisi ) terjadi secara sempurna. Hal lain yang diatur adalah otomatisasi dalam pemberian udara. Pengaturan sirkulasi udara dilakukan setiap 4 kali dalam sehari. Pemberian udara sampai memenuhi kapasitas tangki. Pengaturan tersebut dilakukan pada jam 7 pagi, jam 1 siang, jam 7 malam, dan jam 1 dini hari. Untuk mengetahui kinerja awal sistem dilakukan pengujian menggunakan air terlebih dahulu.

\section{Hasil dan Pembahasan}

Alat yang telah selesai dirancang dan di pabrifikasi perlu dilakukan pengujian. Pengujian alat ini dilakukan selama 5 hari menggunakan air bersih yang bertujuan mengetahui kebocoran pada drum. Tujuan lainnya yaitu mengetahui tingkat kemampuan sistem pengadukam, pompa 
udara, kran udara, dan sensor suhu water proof yang diletakkan di setiap drum. Alat yang telah di pabrifikasi ditunjukan oleh Gambar 2.

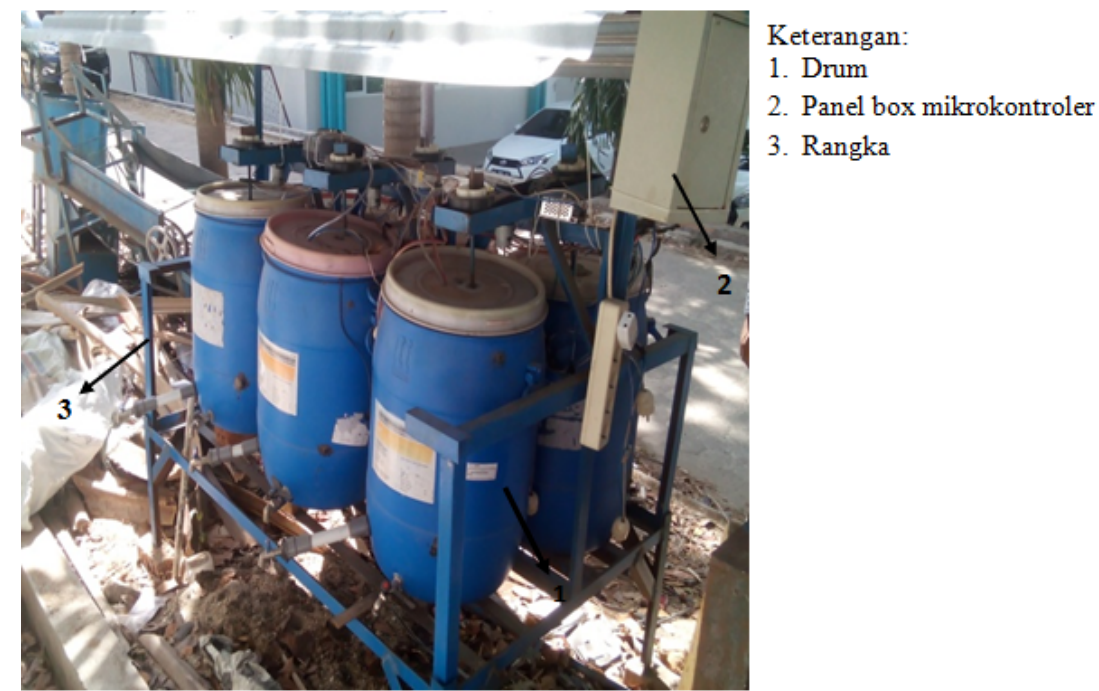

Gambar 2. Alat pembuat pupuk otomatis setelah pabrifikasi

Pada tahapan pengadukan, proses nya diatur oleh pusat sistem kendali (Arduino Atmega). Komponen tersebut mengatur waktu dimulainya pengadukan limbah organik. Pengadukan dilakukan dengan aktuator berupa dynamo DC bertegangan 12 volt dan membutuhkan arus 2 ampere. Dinamo ini dihubungkan dengan gearbox yang terintegrasi dengan pusat sistem kendali (Mikrokontroler Arduino). Kecepatan putaran pengadukan sebesar 30 RPM selama 4 kali dalam satu hari. Tampilan pengolah data dan perintah ditunjukan oleh Gambar 3 dan tampilan LCD sistem ditunjukan oleh Gambar 4.

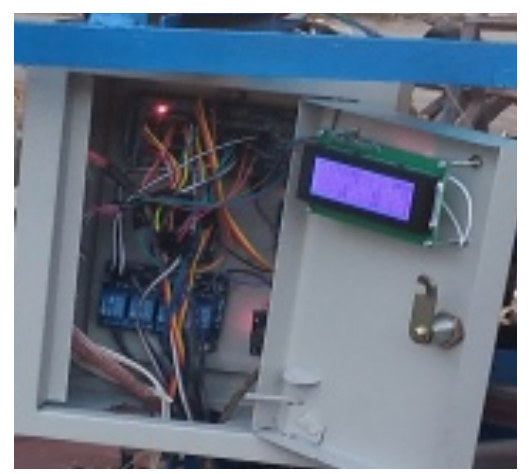

Gambar 3. Bagian pengolah data dan perintah

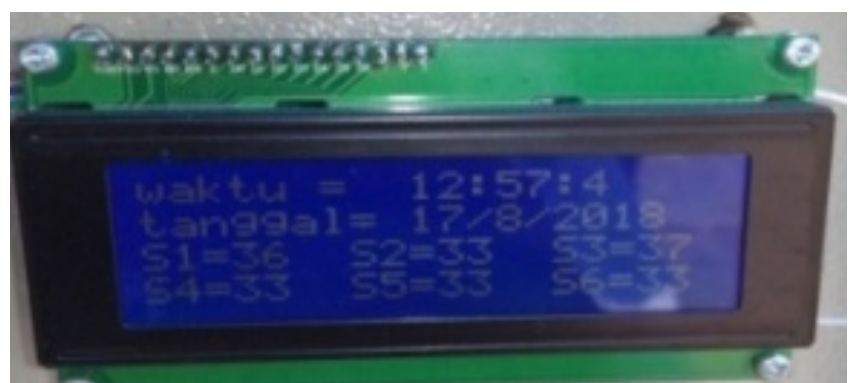

Gambar 4. Tampilan layar LCD sistem 
Jumlah batang pengaduk menyesuaikan jumlah drum dalam sistem sebanyak 6 buah. Selain pengaduk, pompa udara dan kran udara juga dirancang terintegrasi dengan mikrokontroller. Ketika pompa aktif terbuka maka kran udara juga akan terbuka. Pompa ini membutuhkan daya sebesar 50 watt dengan tegangan $220 \mathrm{~V}$ AC, sementara kran udara membutuhkan daya 5 watt dengan tegangan kerja yang sama. Pengadukan dilakukan setiap pukul 06.00, 12.00, 18,00, dan 00.00. Bahan aktuator pengaduk berupa besi yang saling menyilang dan terhubung dengan gear box dan motor DC. Tampilan alat pengaduk dan gear box ditunjukan oleh Gambar 5.

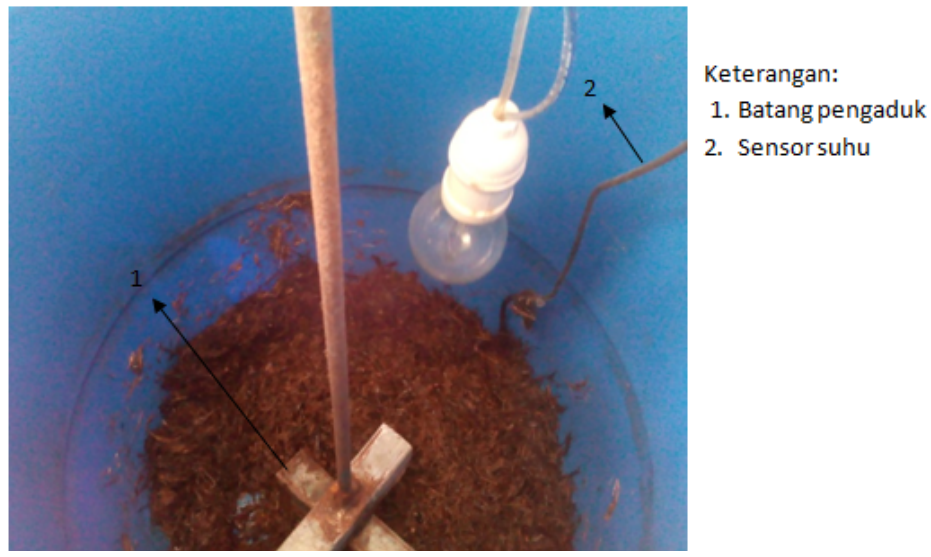

Gambar 5. Komponen di dalam drum

Untuk mengukur suhu menggunakan sensor suhu LM35 bersifat water Proof. Interval suhu yang dapat terdeteksi pada suhu suhu $0{ }^{\circ} \mathrm{C}$ hingga $150{ }^{\circ} \mathrm{C}$. Sensor ini memiliki ketelitian pengukuran sebesar $0,5^{\circ} \mathrm{C}$. Didalam 1 drum terdapat 1 sensor suhu. Suhu terukur setiap 30 menit sekali dan tersimpan secara real time Berdasarkan pengujian yang telah dilakukan didapatkan bahwa suhu yang terukur rata rata berada pada range $23-25^{\circ} \mathrm{C}$. Tampilan peletakan komponen ditunjukan oleh Gambar 6.

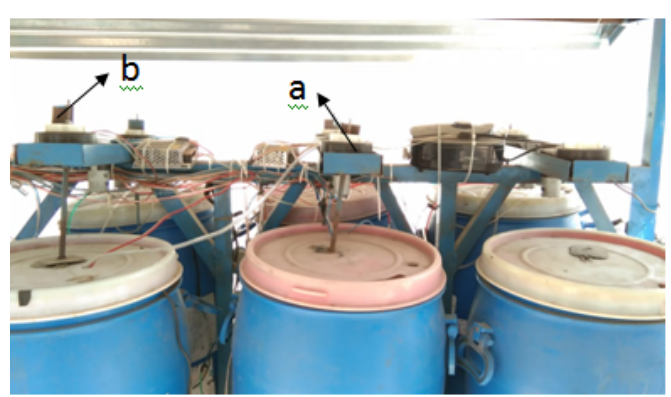

Gambar 6. a) Aktuator pompa udara, b) Gearbox

Sistem telah dilakukan pengujian untuk mengatahui kinerja dati tiap komponen. Hasil unjuk kerja sistem ditunjukan oleh Tabel 1.

Tabel 1. Unjuk kerja sistem pengaduk

\begin{tabular}{llccc}
\hline No & Parameter & $\begin{array}{c}\text { Unjuk kerja sistem } \\
\text { pengaduk }\end{array}$ & $\begin{array}{c}\text { Unjuk kerja kran } \\
\text { udara }\end{array}$ & $\begin{array}{c}\text { Unjuk kerjakran } \\
\text { otomatis }\end{array}$ \\
\hline 1 & Akurasi & $68 \%$ & $99,8 \%$ & $99,8 \%$ \\
\hline 2 & Respon sistem & $\pm 1 \mathrm{mS}$ & $\pm 1 \mathrm{mS}$ & $\pm 1 \mathrm{mS}$ \\
3 & Stabilitas & Stabil & Stabil & Stabil \\
\hline
\end{tabular}


Sistem otomatis menggunakan batang pengaduk yang digerakan oleh dynamo DC $12 \mathrm{~V}$ yang membutuhkan arus 2 Ampere dan terpasang pada Gearbox. Gear box yang terpasang ini terhubung secara vertical melalui sebuah poros berbahan besi. Unjuk kerja yang diukur dari pengaduk dan pompa meliputi akurasi pompa, kecepatan respon, dan stabilitas. Pergerakan aktuator membutuhkan waktu sekitar $\pm 1 \mathrm{mS}$ berdasarkan waktu sistem yang telah diprogram. sistem pengadukan otomatis memiliki akurasi kinerja sebesar $60 \%$.

Setiap sistem diharapkan memiliki akurasi kinerja sebesar $100 \%$ terutama pada sistem pompa udara. Berdasarkan data pengujian yang terekam didapatkan akurasi kinerja sebesar 99,8\%. Penyebab terjadinya perbedaan nilai dari yang diharapkan karena matinya jaringan listrik saat pengujian berlangsung. Sistem membutuhkan waktu $\pm 1 \mathrm{mS}$ untuk menghidupkan aktuator pompa udara untuk setiap target waktu yang telah direncanakan. Hasil ini menunjukan respon sistem memiliki nilai tergolong baik. Pengujian stabilitas pompa udara dilakukan dengan mengamati pergerakan pompa sebanyak 7 kali pengamatan dengan waktu yang telah diatur. Hasil pengamatan pompa menunjukan bahwa sistem pompa dalam keadaan stabil.

Alat pembuat pupuk otomatis ini saling mengintegrasikan komponen dengan sistem pusat kendali Salah satunya pompa udara yang terhubung dengan kran udara dalam proses sirkulasi udara kedalam drum. Hasil akurasi kinerja saat pengujian didapatkan sebesar 100\%, akan tetapi berdasarkan data yang terekam akurasi kinerja sebesar 99,8\%. Penyebabnya adalah matinya jaringan listrik saat proses pengujian dengan perekaman data. Untuk sistem kran otomatis ini membutuhkan waktu $\pm 1 \mathrm{mS}$ saat menghidupkan dan membuat terbukanya kran sesuai dengan waktu yang atur sebelumnya. Waktu pembukaan yaitu pada pukul 07.00 pagi, 13.00 siang, 19.00 malam, dan 01.00 dini hari. Pada proses pengujian stabilitas kran otomatis yang diamati secara acak sebanyak 7 kali pengamatan, diperoleh kran otomatis dapat dikatakan stabil.

\section{Kesimpulan}

Alat pembuat pupuk otomatis terdiri dari 6 drum yang dilengkapi dengan gearbox, batang pengaduk, pompa udara, kran udara, dan kran otomatis yang terintegrasi dengan mikrokontroler Arduino. Hasil pengujian didapatkan untuk kinerja sistem pengaduk sebesar $68 \%$ dan respon sistem sebesar $\pm 1 \mathrm{mS}$. Waktu pengadukan pada pukul 06.00 pagi, 12.00 siang, 18.00 sore, dan jam 12 malam. Hasil pengujian pompa udara memiliki akurasi pengerjaan sebesar $98 \%$ berdasarkan data yang terekam dan respon sistem untuk penyalaan sebesar $\pm 1 \mathrm{mS}$. Keseluruhan sistem menunjukan tingkat kesetabilan yang baik, sehingga alat dianggap layak dalam membuat pupuk organik berbahan dasar limbah TKKS.

\section{Daftar Pustaka}

Anastasia, I., Munifful, I., \& Suedy, S. W. A. (2014). pengaruh pemberian kombinasi pupuk organik padat dan organik cair terhadap porositas tanah dan pertumbuhan tanaman bayam 
(Amarantus tricolor L.). Jurnal Biologi, 3(2), 1-10.

Eka, N. (2000). Pemanfaatan tandan kosong kelapa sawit sebagai sumber bahan kimia. Warta PPKS 2000, 8(3): 137-144.

Dwicaksono, M. R. B., Suharto, B., \& Susanawati, L. D. (2013). Pengaruh penambahan effective microorganisme pada limbah cair industri perikanan terhadap kualitas pupuk cair organik (Effect of effective microorganisms additions on the wastewater from fishing industry for organik liquid fertilizers). Jurnal Sumberdaya Alam \& Lingkungan, 7-11.

Joewono, A. \& Agustine, L. (2015). Otomatis-elektrik tenaga surya untuk pengolahan sampah organik .Seminar Nasional Energi Telekomunikasi dan Otomasi (SNETO)-ISBN 978-60273246-0-2

Nurisman, H. D. (2019). Alat Pengolah ampas tahu menjadi pupuk cair organik dengan pengepresan pneumatik dilengkapi pengisian bahan otomatis. 193-200.

Saraswati, R., \& Heru, R. (2017). Percepatan proses pengomposan aerobik menggunakan biodekomposer / Acceleration of aerobic composting process using biodecomposer. Perspektif, 16(1), 44-57.

Simatupang, H., Nata, A., \& Herlina, N. (2012). Studi isolasi dan rendemen lignin dari tandan kosong kelapa sawit (Tkks). Jurnalnteknik Kimia USU, 1(1), 20-24.

Sucipto, E., \& Hendariyono, J. (2018). Rancang Bangun Alat Disck Granulator Skala Laboratorium Pembuatan Pupuk Granul Organik Mikro Organisme Lokal ( MOL ).. Seminar Nasional Hasil Penelitian dan Pengabdian Masyarakat 2018, ISBN: 978-60214917-5-1. hal 213-220

Supriatna A. S., Putri, R. I., \& Nanik H. (2015). Pada Proses Pembuatan Pupuk Organik. Jurnal ELTEK, 13(01), 1-10.

Warsito, J., Mulyani, S., \& Mustapa, K. (2016). Fabrication of Organik Fertilizer From Waste of Oil Palm Bunches. J. Akademika Kim. 5(1), 8-15. 